\title{
THE ROLE OF IT GOVERNANCE IN DIGITAL OPERATING MODELS
}

\author{
Christian Hitz \\ University of Economics, Prague, Czech Republic \\ Karlheinz Schwer \\ University of Economics, Prague, Czech Republic
}

\begin{abstract}
Many researchers have dedicated their work in IT Governance, and numerous methods, techniques and tools for making decisions to align IT to a business strategy were proposed in the last decade. In the meantime, new digital business models developed rapidly and aligning business with IT has become more difficult than ever. Governance frameworks are widely used to reduce complexity in the decisionmaking process and organisations tend to use several topics related governance frameworks besides IT Governance. Different governance frameworks are related, dependent and interact under each other, and since they all have their own method of measurement and evaluation, the interaction suffers from a lack of data consistency or they do not take all dimensions of decision-making into account. Furthermore, the lack of consistency is caused by the definition of governance frameworks itself and leads to concurring goals among governing bodies. This paper proposes a design goal for a method of measurement by (1) critically reviewing the existing state of art of measurement and evaluation concepts of governance frameworks, by following a comprehensive review of the normative literature dealing with the measurement aspects of IT Governance, and (2) analysing a dataset $(\mathrm{n}=51)$ of a preliminary study done in spring 2017 with Swiss companies.
\end{abstract}

Keywords: Corporate Governance; IT Alignment; IT Governance; ISO 38500

DOI: http://dx.doi.org/10.15549/jeecar.v5i2.210

\section{INTRODUCTION}

Is digital transformation just a hype or has it already became real? When the big players go digital and smart machines have chats in the cloud, mid-size companies must shift their view of Information Technology (IT) as a simple cost factor to IT, as a strategic asset in the world of digital business models. The change of these business models will change the classic views of management. Robbins and Coulter (2012, p. 156) state that "the most visible technological changes have come from computerization". This was true, since the very beginning of the use of something called a computer. In that sense, the digital transformation started with the first steps of computing. Computing became different after 1945, where these systems were seen for the use of military needs (Ceruzzi, 2003). In the 70s, lower prices opened the way to the first personal computer, and automation with electronic tellers for banks started. It was the first wave of the revolution of IT. The OECD Council (2005, p. 6) states that "many services sectors have experienced rapid employment growth, though only some have also experienced rapid productivity growth...over 
the past decade, these services accounted for around $60 \%$ of all employment created in the OECD area." No wonder, in the 80s and 90s, computerization has become the topic of social controversy (Kling, 1996). The question was: "Will future business models just follow technology, or will IT have to follow business"? Innovative business models and strategy became the focus of strategic management. One good example of re-inventing the business model has been shown by the Blue Ocean approach of Kim and Mauborgne (2004). But only ten years later, innovation cycles have become much faster with disruptive business models, and they are driven by digital opportunities (Bashir, Yousaf, \& Verma, 2016). Will there be a choice of NOT following IT in the future? Industries began to copy or/and transform business operating models in their industry or consult each other (Detsky \& Garber, 2016). Brühn et al. (2014) ask whether these new business models are just another form of sharing economy. Challenges of shared economy business models have been discussed in the last couple of years. Shared economy examples, such as "airbnb.com" or "booking.com" changed the game in the hospitality industry within a few years. Kagermeier, Köller, and Stors (2015) discuss the challenges the hospitality industry has to face in the city of Berlin. The article concludes that the market in Berlin has been put upside down by the shared economy model of "airbnb". Many industries are uncertain whether they will encounter similar situations. Many open questions and fears are currently discussed in the literature. Management journals are filled with articles about the new situation of disruptive business models, shared economy or industry 4.0. Managerial issues are often discussed in the context of IT Governance which shall be discussed in this article.

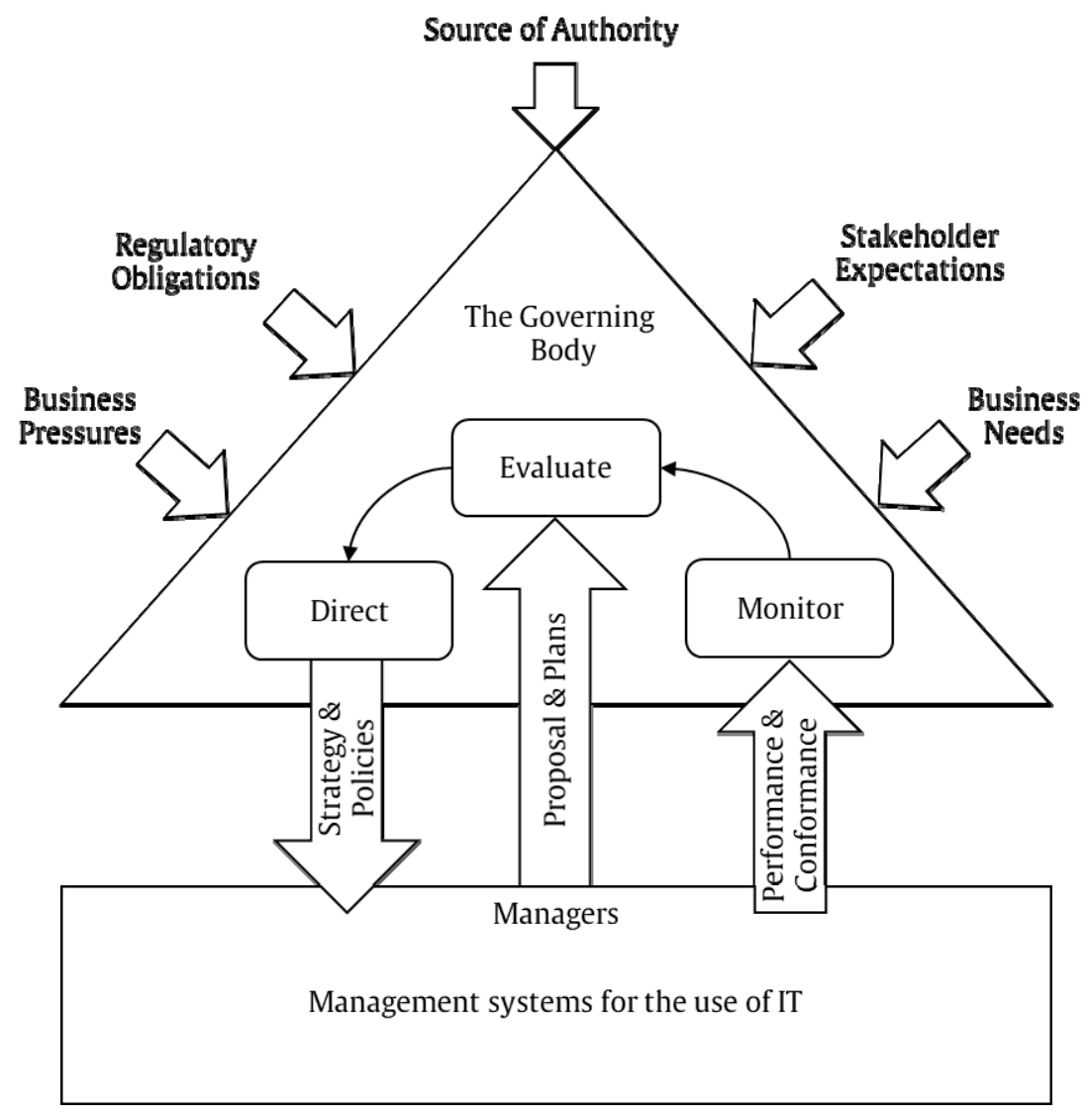

Figure 1. Model for governance of IT (adapted from ISO/IEC 38500:2008), (ISO/IEC TR 38502:2014).

The Governance theory is an old concept of governmental organizations. Governance as a term is used in various disciplines and is not new. It “... has been used for the description of decision-making processes and following implementation, frequently being associated 
merely with the government and public administration" (Potůček, Veselý, \& Nekola, 2004, p. 25). IT Governance as a model does not make an exception as to be primarily a model to take decisions in the context of information and communications technology, or technologies (ICT). There were already approaches to IT governance in the 1960s, such as IBM's Business Systems Planning (BSP). Zachman's framework was based on this. He introduced it in the IBM systems journal in 1987 (Zachman 1987). There have been other approaches such as the US Department of Defense (DoD)'s so-called Technical Architecture Framework for Information Management (TAFIM), which also may be claimed as an early form of IT Governance (Hanschke 2010; Perroud \& Inversini, 2013). Weill and Ross (2004) took the concept of understanding IT Governance as a decision-making process. They identified fields of IT decisions with the idea to align business and IT objectives by translating business principles into IT principles (Fink \& Ploder, 2008). It shows that IT Governance takes many aspects and perspectives of business and different architectures into consideration. The evaluation of all relevant information plays an important role in the decision-making process and data consistency is utmost crucial. Today, existing IT Governance concepts follow ISO 38500 , the framework and model for IT Governance. This model shows the importance of measurement systems and evaluation in Figure 1 (ISO/IEC, 2014).

The framework contains basically two major bodies, (1) the governing body, where the evaluation takes place and (2) the management systems for the use of IT, where strategies and policies are supposed to be adapted. In addition, the ISO/IEC (2014) model shows external factors which take an important role in the evaluation. The model considers the factors (1) Business Pressures, (2) Regulatory Obligations, (3) Stakeholder Expectations, (4) Business Needs and (5) Source of Authority. These factors show that decisions made in the governing body are dependent on external information or other governance frameworks. The model is an inbound view of IT Governance. However, this model does not contain outbound relations to "design principles on methods of collecting data." But this method would be crucial to the information that will be available to any board that takes decisions. Such missing items are primarily necessary to understand the already addressed topics in the measurement of governance in state of the art. Thus this paper will not only show results of preliminary research to show the role of IT Governance in the digital era but also aims to address future research concerning the measurement in the context of IT Governance.

\section{Paper goals and contributions}

The authors have chosen a multi-method approach in order to show the relevance of the method of measurement in the context of governance theory. Thus, this article has two outcomes.

The first expected outcome is a carefully implied analysis of the literature (A) considering the alignment topic that has been performed. The analysis of the literature had the following review goal [RG]: Which different models of change exist in the context of IT Governance? In addition, two supporting questions have been raised:

(RQ1) Is there a missing IS-Business alignment due to missing methods of change management or IT Governance standards?

and

(RQ2) In the context of ISO 38500, which dimensions describe a general operating model to define and ensure IT Governance in digital business models?

The second expected outcome is the analysis of a (B) preliminary study executed in spring 2017 among a selection of Swiss companies $(n=51)$. The preliminary study has been performed to validate the existence of IT Governance in the chosen Swiss Companies. In addition, the study represents the maturity of the companies in the context of digital readiness. The question that has been relevant to this paper was: (RQ3) "Do Swiss companies have a sound readiness to implement digital business models?"

\section{RESEARCH METHOD}

\section{Theoretical Framework}

The theoretical framework of this article applies to the research design science research paradigm (DSR) of information systems (Hevner, March, Park, \& Ram, 2004). Hevner (2007) distinguished between three different cycles: (1) relevance cycle, (2) build/evaluate 
cycle and the (3) rigor cycle (Hevner. 2007). This article relates to the first cycle, the relevance cycle of the DSR and according to Hevner (2007), it shall bridge "the contextual environment of the research project with the design science activities" (p. 88). This theoretical framework has been chosen because the research goes towards a design for consistency of data in governance in order get a common information base for decision making. It is not seeking what is true, as this is in the nature of a behavioral-science paradigm. According to Hevner et al. (2004), in contrast to the behavioral-science, the design-science paradigm seeks to create a solution that is more effective. Following Hevner's (2004) guidelines, DSR contains seven mandatory elements which can also be found entirely or partly also in other DSR related methods such as Österle and Otto's consortial research method (Österle \& Otto, 2010). In both methods, there is (1) an IT artifact in the form of a real solution that (2) solves a relevant problem. This solution shall be (3) evaluated rigorously and shall (4) provide a research contribution. Further (5) rigorous methods shall be (6) carried out as a search process and (7) shall be communicated. Österle and Otto (2010) mention five important elements in the process that can be applied iteratively. First, there is a domain (1), the roam of research, the state of the art or best of the breed which is about to become more effective. Four research stages follow, (2) the analysis of the existing artefacts, (3) the design/build of reference models/models or/and methods, (4) the evaluation of solutions in practice and (5) the diffusion which is to communicate results to the research community. This is a common approach for DSR projects. According to Peffers, Tuunanen, Rothenberger, and Chatterjee's (2007) process model, such projects follow the steps (1) problem identification, (2) objectives of a solution, (3) design and development, (4) demonstration, (5) evaluation and (6) communication. Comparatively, the relevance cycle from Hevner (2007), the analysis from Österle and Otto (2010) and the problem identification from Peffers et al. (2007) are equal steps in the process and partly covered by this article. Sonnenberg and Vom Brocke (2012) describe all evaluation activities in a DSR framework. This paper is focussing to their "ex ante evaluation". It is basically identifying the problem, and evaluates this finding by validating it in the sense of Hevner's "relevance cycle" (Hevner et al. 2004).

\section{Expected outcomes}

The first outcome of this paper relates to existing related work. Several literature reviews have been taken into consideration. In general, ta literature review has several characteristics such as (1) focus, (2) goal, (3) perspective, (4) coverage, (5) organisation, and (6) audience (Cooper, 1988). It can be summarised that following Cooper's taxonomy (Cooper, 1988), the literature analysis would mainly be set up as the (1) focus to be research outcomes, the (2) goal to be identification of central issues, the (3) perspective to be exhaustive, the (4) organization to be conceptual, and the (5) audience to be practitioners or policy makers. However, the main papers that influenced the first outcome are described in related work.

The second outcome relates to a preliminary study that had been performed in spring 2017 in Switzerland. The study was a replication study of two surveys and an additional construct made for the study. The questionnaire of the first part of the survey was based on the constructs of the Wu, Straub, and Liang (2015) survey. The second part was based on the literature by Westerman, Bonnet, and McAfee, (2014) and the study by Westerman, Calméjane, Bonnet, and McAfee (2011). An additional construct was necessary to add an additional aspect onto $\mathrm{Wu}$ et al. (2015) study. The construct relates to Figure 1 in which IT Governance has explicitly used data gathering and monitoring elements for its evaluation. Wu et al. (2015) had their focus on influence to organisational performance, where the focus in the preliminary study was on the relationship of IT Governance towards digital readiness and the replication study. All constructs and questionnaires remained as defined in the former studies. Both surveys and the additional construct used a Likert (1932) scale which made the comparison of the two models possible (Lubke \& Muthén, 2004). The main goals of this second outcome were (1) to get a better understanding of the current status in IT Management maturity using IT Governance Mechanisms and (2) their efforts towards digital transformation strategies and activities. In addition, the preliminary study validated Hevner's (2007) problem space in the relevance cycle. 


\section{Related work}

In the past decade, many researchers have dedicated their work on the topic of IT Governance. Several literature reviews have been published.

\begin{tabular}{|ll|}
\hline $\begin{array}{l}\text { Meta Literature } \\
\text { Review }\end{array}$ & $\begin{array}{l}\text { Articles covered in the } \\
\text { Literature Review } \\
\text { sec,tion }\end{array}$ \\
\hline Wu et al. 2015 & 9 \\
\hline $\begin{array}{l}\text { Brown and Grant } \\
\text { 2005 }\end{array}$ & 76 \\
\hline Weill and Ross 2004 & 60 \\
\hline Webb, et al. 2006 & 12 \\
\hline $\begin{array}{l}\text { Chan and Reich } \\
\text { 2007 }\end{array}$ & 156 \\
\hline
\end{tabular}

The selection of recent publications and literature reviews influenced this paper most. The papers are (1) Eom, Kahai, \& Yayla (2015), (2) Wu et al. (2015), (3) Maryska, Doucek, \& Nedovema (2015), (4) Ruoss (2015), and (5) Ali \& Green (2012), all of which influenced the first expected outcome.

\section{DISCUSSION}

\section{Transformation}

The difference between terms like change management, transformation, and the transition is not always obvious. In practice, these terms are easy to be used as synonyms. But transformation always stands in the context of change management. Change management has become one of the main disciplines of management. Research shows that $70 \%$ of all organisational change management projects do not meet the set goals (Bracken, 2014). Lauer (2014, p. 4) mentions an important difference, that "change management generally stands for the steering of company change" and is not a method with approaches for management by objectives. The focus is more on what to steer (i.e., targets, strategies) and not how to lead involved people that are affected by the change (Bracken, 2014). So change management is often linked to the organisational change of a company and is actively steered by the management.

In most cases of practice, change management only affects parts of the company, and this does not necessarily have a major impact on the whole organisation (Lauer, 2014). The change is triggered by different internal or external factors. External factors can be new competitors, change of technology or the change of the political situation (Lauer, 2014). With these external factors, an organisation is forced to react with a certain urgency (Pescher, 2010). On the other hand, an internal trigger such as the development of new markets can be seen as a change to manage proactively. In most of the cases, higher turnover, lowering costs, and reaching higher productivity and effectiveness are the most common drivers and triggers for change. Pescher (2010), shows five different perspectives for understanding organisational change (Figure 2).

Transformation can be defined as part of an internal or external organisational change. With this definition, the digital transformation must be seen as a form of change management with either external or internal factors as drivers of the change. In that context, it is important to distinguish between organisational factors and technology factors. Another perspective is mentioned by Bridges (1991) who is looking to factors of the sociology of knowledge. In this perspective, external factors are factors of a certain situation and all cognitive processes of the involved persons are called the internal factors. The psychological process is called the transition. Omitting this transition, a change will fail according to Bridges (1991) who has a simple equation for this transition. 


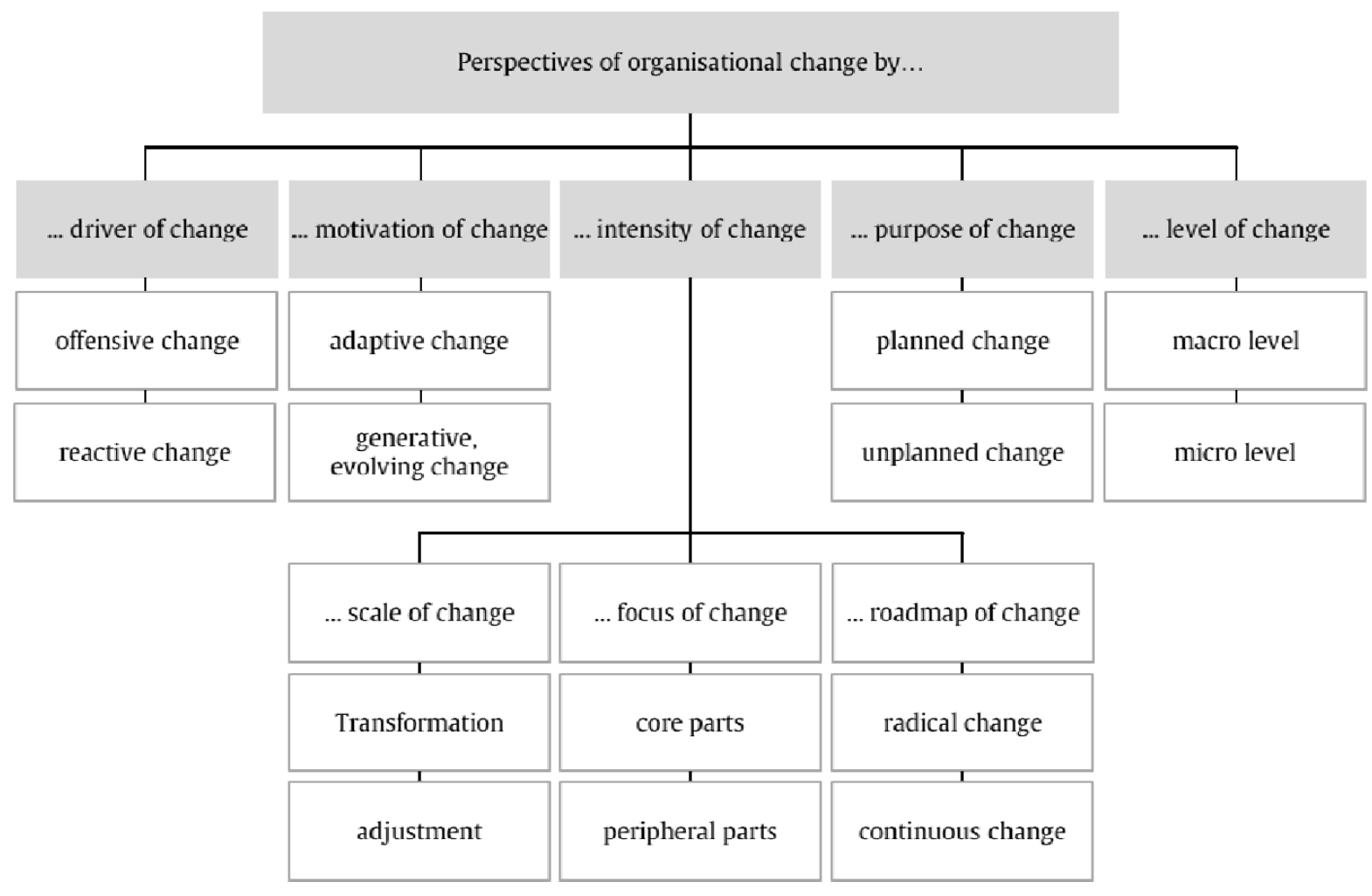

Figure 2. Perspectives of organisational change (Pescher 2010)

\section{change + human beings = transition}

There is a small difference between the terms transition and transformation. Transformation is triggered by various factors. In the sense of Bridges (1991), a transition, on the other hand, starts always with an end. It then passes a neutral zone and ends up with a new start. These phases are not timely closed processes; they overlap to a certain extent (Bridges 1991).

Figure 2 shows different perspectives of organisational change. Organisational transformation can be divided into "corporate transformations" and/or "modular transformations." The first form, the corporate transformation stands for a radical, fundamental change of a company. It will then define a completely new strategy, business model and operating model. A modular change could be more be seen as a restructuring on the divisional level (Pescher, 2010). Hernaus (2008, p. 5) of the University of Zagreb found a good definition of "corporate transformation" in his working paper:

"It could be classified as a type of radical change because the organizational transformation is about pursuing new and different strategies, structures, processes, rewards, capabilities, and resources, supported with new and different core values - new culture."

When organisational transformation happens, ITC will be affected either directly or indirectly. Snyder $(2014$, p. 1$)$ relates this fact. He defines IT-transformation as follows:

"IT transformation is comprehensive change to an IT organization that cuts across its processes, technologies, culture, and sourcing and delivery models that enables continuous step-change improvements in business capabilities supported by significantly stronger IT capabilities at lower unit costs."

It can be concluded that business ITC transformation will radically change organisational structures of a company or division. It will change in parallel elements of all levels of management. Following a roadmap, management approaches to change management will affect the firm at normative, strategic and operative levels. Modal objectives, we may say milestones of the roadmap, will be achieved with transitions, which include organisational change but also changes of corporate culture. 


\section{EGIT Enterprise Governance of IT}

In literature, an IT strategy is always based as part of the business strategy (Johanning, 2014). IT Governance is derived from the Corporate Governance of an enterprise but also from the IT strategy. This is the reason why IT Governance should by placed on the enterprise top management level, rather than seen as an operational level (Johanning, 2014; Maryska et al. 2015). Haes and van Grembergen (2015) chose a different approach for defining the term IT Governance. Because the term IT Governance relates to IT, Haes and van Grembergen (2015) prefer to call it "EGIT -Enterprise Governance of IT" instead of IT Governance (Haes and van Grembergen, 2015). Maryska et al. (2015) and Johanning (2014) define the goal of Enterprise Governance of IT in supplying processes, structures, methods in order to support the fulfillment of the goals of an IT strategy (and this also includes business strategy goals). It organises IT within the enterprise and defines authority to decide in IT matters (Johanning, 2014). EGIT is not affected by the size of an organisation (Wu et al. 2015; Chan \& Reich, 2007). In other words, EGIT can be done with any organisation. Only the scale of implementation can vary (Maryska et al. 2015; Wu et al. 2015). The result of implementing an EGIT will enable the organisation to align and adjust business and IT (Haes \& van Grembergen, 2015).

\section{Recent studies}

Ruoss (2015) surveyed in Switzerland. The survey of his master thesis comes to an interesting conclusion. 56\% of the 463 ITprofessional participants see themselves as digital dinosaurs. Only 26\% see themselves as matured "Digital Masters" (Ruoss, 2015). 73\% clearly state that digital transformation will be critical for success in 2020 (Ruoss, 2015). This small survey shows that mid-size firms discuss digital transformation as a critical path to follow. But where do these firms stay today? Where do they start to transform? Most see themselves not as agile, and the cost for transformation is seen as to be big. In addition, the necessary maturity is not existent, and the know-how is weak. Gartner stated in 2014 "You must build talent for the digital organization of 2020 now. Not just the digital technology organization, but the whole enterprise. Talent is the key to digital leadership" (Gartner Group
2014 , online). But it is not the only talent. Eom et al. (2015, p. 8) conclude that IT leadership is "positively related to mechanisms to develop shared domain knowledge" and "shared domain knowledge was positively related to IT-business alignment." It shows the dilemma of firms that optimise their budget to maximize profits and do not invest into domain knowledge and ITbusiness alignment. Now a necessary substance is missing to move in a direction that is seen to be the key enabler in order to stay in the market. Ruoss (2015) states that $74 \%$ of the surveyed firms see major impacts in their branch through a digital transformation in the next 5 years, and more than half (52\%) are treating it as a key success enabler within the next 2 years. But why do firms see themselves as digital dinosaurs? Is it caused by the pressure of the shrinking margin? Is it caused by the lack of a sound IT strategy that is aligned with the business model? Is it caused by missing understanding or lack of IT Governance? Weill and Ross (2004, p. 215) state that "IT Governance is the decision rights and accountability framework for encouraging desirable behaviours in the use of IT". In the last twenty years, many methods have been developed for supporting firms to manage their IT with respect to IT Governance. Methods like CobiT (Goltsche, 2007), Zachman Balanced Scorecard (Zachman, 1987) and others play an important role in Enterprise Architecture and IT Governance. One of the first approaches is seen in Zachmans introduction of a framework for information systems architecture (Zachman, 1987). This approach was supposed to prevent firms from becoming dinosaurs. Obviously, the current understanding of enterprise governance of IT, which also includes IT strategy, does not work for most mid-size firms. Because of the size of the company, firms tend to omit a clearly defined IT strategy. Chan and Reich (2007) explain this with good communication structures within very small firms. However, they also say that alignment does show less evidence, when the organisation structure becomes bigger. So in practice, also large companies lose track when the organisation becomes very big. The lack of transparency will lead to incorrect decisions. It becomes obvious that communication becomes a key factor of alignment. Chan and Reich (2007, p. 307) argue "When shared domain knowledge was high, communication between the two groups was strategic and frequent, and the result was a high 
level of alignment". In various studies, Weill and Ross showed that firms get more profit from IT investments than their competitors by simply designing, implementing and communicating processes of an enterprise governance of IT ( Wu et al., 2015, p. 498). Looking on the summary table of Prior Research on IT Governance Mechanisms in Wu et al. (2015)'s study, we can see that many research findings can be linked to communication. Ali and Green (2012, p. 180) state in this context:

"The existence of governance mechanisms such as: (1) a culture of compliance in IT; (2) corporate communication systems support; (3) involvement of senior management on a regular basis; and (4) a corporate performance measurement system significantly impact the level of effective IT Governance".

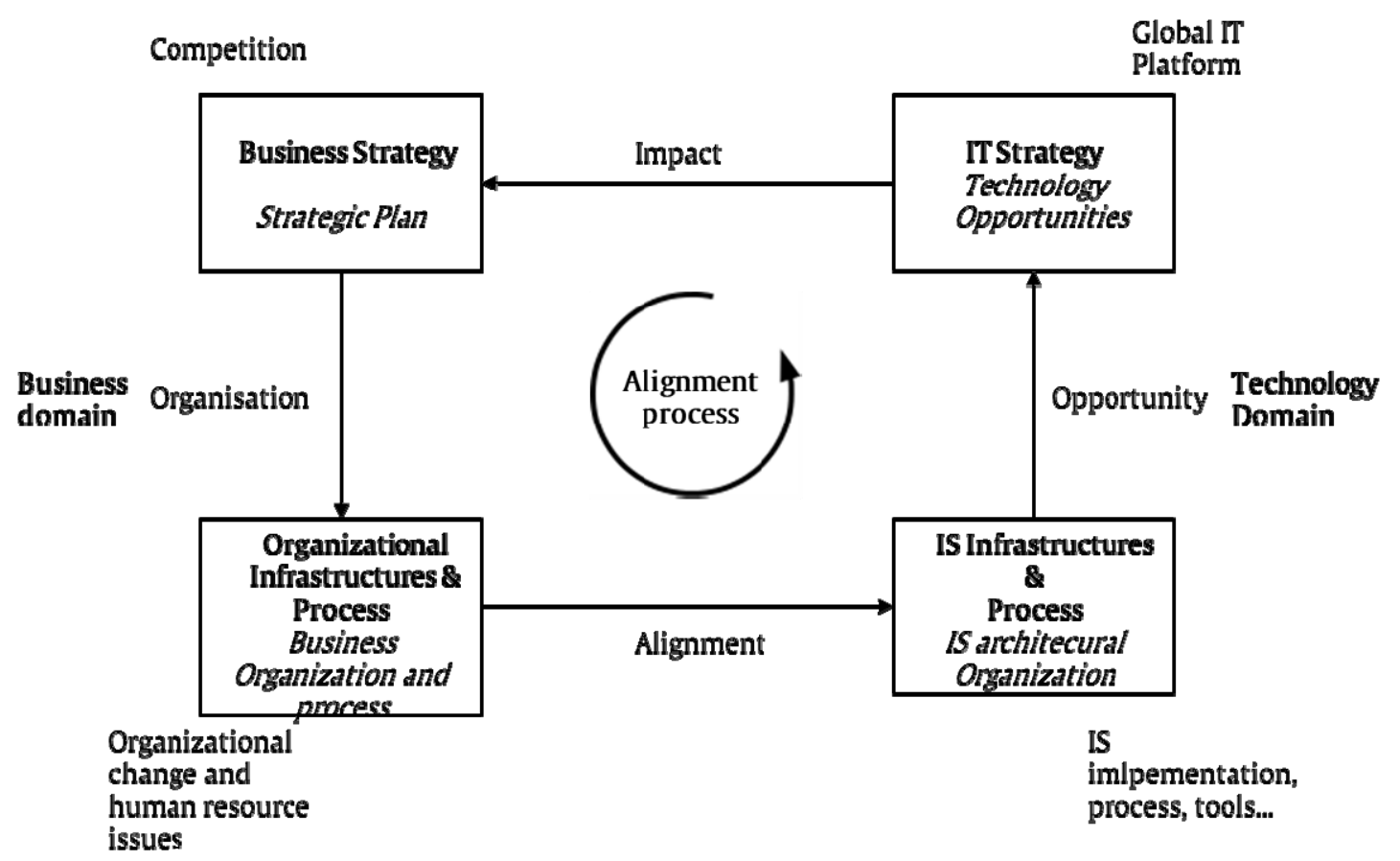

Figure 3. The Baets model, (Baets, 1992, p. 207)

The missing knowledge or not well-defined enterprise systems of IT Governance automatically lead to mismanaged IT. The Baets model introduced by Baets (1992) showed this long before the IT Governance discussion started. Figure 3 shows that model. The model has also been proven by the study of Venkatraman, Henderson, and Oldach (1993). Having had well-defined models of alignment and studies for over twenty years and comparing the fast technology cycles in these years, it is difficult to understand how $56 \%$ of Digital Switzerland studies see themselves as dinosaurs, in other words, not seen themselves ready for digital business models. This selfassessment is impressive for a country where many companies run an offensive digital strategy. An online survey of the Swiss CIO online platform (www.inside-it.ch) among its business manager readers shows that more than
$50 \%$ run an offensive digital strategy. The gap between capacity and competency, between wish and reality, cannot be described better. IT and business seem not to be aligned.

\section{CONCLUSION FOR FIRST EXPECTED OUTCOME}

The problem of misaligned enterprise governance of IT is not based on the lack of models and approaches. On the contrary, future management needs to learn and understand that management does always deal with all domains of an operating model. Publications like Eom et al. (2015), Chan and Reich (2007), and Weill and Ross (2004) show that a high level of communication will lead to higher IT alignment. Findings are also shared from Venkatraman et al. (1993) and Baets (1992). If IT Governance is also understood as a model for changing a system, the Review Goal [RG] may be 
answered as "a lot of old and new models exists in the field of IT Governance theory." However, the results show that many researchers like $\mathrm{Wu}$ et al. (2015), Ruoss (2015), Eom et al. (2015) and Ali and Green (2012) have done extensive studies about IS-Business alignment. But the question (RQ1) must be answered with "no." There have already been well-established bestof-breed approaches of change management and standards of IT before IT Governance with its methods as an approach has become available. It also explains why a lot of firms have no definition of IT Governance at all, although studies predict higher performance in the use of it. Thus, the authors come to the conclusion that it is not a lack of knowledge of governance- or change-theory which leads to of misalignment, but the wrong perception of the managed environment, the operating model. An incomplete or inconsistent information base is the source of misalignment of IT- and businessstrategies.

\section{General digital operating model}

(RQ2) searches for a general digital operating model. The latest version of ISO/IEC 38500 (2015) lets one derive such a general operating model. Further, Pescher (2010) showed the different interaction perspectives of change. Early approaches of Zachman (1987), Baets (1992), Venkatraman et al. (1993) and Weill and Ross (2004), can be taken into consideration while proposing a general operating model for digital business models. The main difference between these approaches is the fact that in digital business models it is difficult to determine where the company is in action. The authors conclude that digital business models deal not with particular actors but with communities. The proposal starts from Figure 1 (ISO 38000) that is deriving dimensions and groups of actors. Four main dimensions of a digital operation model have been discovered. Each dimension has a corresponding community where engagement and therefore digital or real communication takes place. The analysis of an organisation along these dimensions lets one understand the organisation, middle and long-term plans, process and road maps, the strategy, the relationships and communication to communities of a certain operation. A general operating model is generic and applies to any kind of operating model. The model in Figure 1 lacks outbound connections. In a generic operating model, all interaction from outside and inside must be covered. This can be achieved by the construct of communities. In communities, the direction of communication is not given, it can go in any and multiple directions. For RQ2 the authors introduce a general digital operating model. It is important to understand that the word community stands for an undefined sum of interactions either with social or pure digital nature. A number of elements and the number of interactions are by definition not known. The dimensions (with the corresponding community) with typical questions (examples) are:

Dimension (1) Authority (stakeholder community):

Who are the stake- and shareholders? Where do ideas of the model come from? Who are the innovation drivers of the model? How is the future of this operating model or this division seen from senior management of the company? Are there questions of compliance and conformance?

Dimension (2) Competency (peer community):

How are competencies developed? Is there a peer-community of the competency? Who are our peers, the subject matter experts, the competitors and what does their operating model look like?

Dimension (3) Enabling (supplier community):

Who are the partners of the operating model? How do we engage our suppliers? Do we have a choice?

Dimension (4) Capacity (market community):

What is our value proposition? Who are the customers? How is this market structured? 


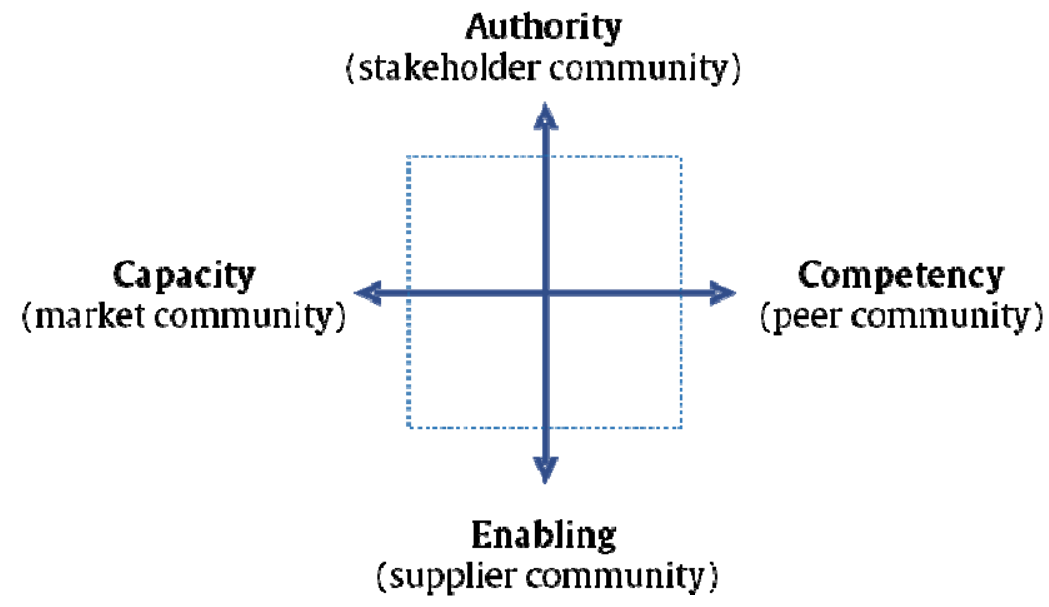

Figure 4. Dimensions of a general digital operating model

This simple model lets one understand that communication differs from dimension to dimension. Different subject matter experts and knowledge domains (competency) speak different languages. Subject matter experts speak another language among their peers. Stakeholders (authority) have other interests than members of the supply chain (competency, enabling). Defining new digital business operating models need to recognize, that markets (capacity) will be addressed differently. For future management, it implies that future digital business models will link a business operations model and an IT operations model tightly. The models may easy become congruent. We also saw in all recent studies, that IT business alignment can be achieved through high levels of communication. Understanding each other is a prerequisite of that fact. This also implies that the knowledge (competency) in information management will become a mandatory skill set of any future management. The introduced general operating model is generic and lets one understand the basic difference of different knowledge domains of communication. But communication between business and IT is just one of many communications styles. Mastering different communication styles will become a key asset for future management to compete with digital business models. As Digital Switzerland (Ruoss, 2015) study showed, established structures of big companies are not that agile as for small enterprises. Enterprise Governance of IT is not widely-used although the benefits are evident and proofed science-based. Many authors, therefore, see the digital transformation as a chance for SME's to reinvent their business strategy and business operating models (Kagermann, 2011).

\section{Digital readiness study}

Data

The study has been based and cross-validated with existing literature analysis in the research community such as articles from $\mathrm{Wu}$ et al. (2015), Ali and Green (2012), Otremba (2016), Ruoss (2015) and Westerman, et al. (2011). Table 1 lists the volumes of questionnaires that have been distributed. The return rate of $79 \%$ (247 questionnaires) showed successful participation. However, after cross-validation, only 51 questionnaires remained for further analysis. Table 1 shows the quantity structure of the dataset collected in spring 2017.

Table 1. Return rate and quantity structure of the of the digital readiness study 2017 dataset

\begin{tabular}{|lll|}
\hline & $\mathrm{n}$ & $\%$ \\
\hline Surveys distributed & 312 & $100 \%$ \\
\hline $\begin{array}{l}\text { Surveys not } \\
\text { answered }\end{array}$ & 65 & $20.8 \%$ \\
\hline Surveys returned & 247 & $79 \%$ \\
\hline $\begin{array}{l}\text { Surveys (failed cross } \\
\text { validation) }\end{array}$ & 196 & $62.8 \%$ \\
\hline $\begin{array}{l}\text { Surveys (successful } \\
\text { cross validation) }\end{array}$ & 51 & $16.3 \%$ \\
\hline
\end{tabular}


The results have been restricted to results of subject matter experts, working on a middle- or $C$ - management level.

\section{Results for the second expected outcome}

The questionnaire was divided into 13 questionnaire sections. Each section had a minimum of 3 questions per construct. In this paper, the focus is on results for RQ3. However, the comparison to the study of $\mathrm{Wu}$, et al. (2015) is also of interest. The main three findings of the
IT Governance section and Digital readiness shall be discussed.

Figure 5 shows the results regarding IT Governance Mechanisms. Only 9\% claim to have proper IT Mechanisms installed. According to the results, half of the participating Swiss companies state that there is no existence of IT Governance structure. This result reflects the study of Ruoss (2015) where many IT leaders claim their IT to be dinosaurs. Only 9\% strongly agree to have proper IT Governance structures in place.

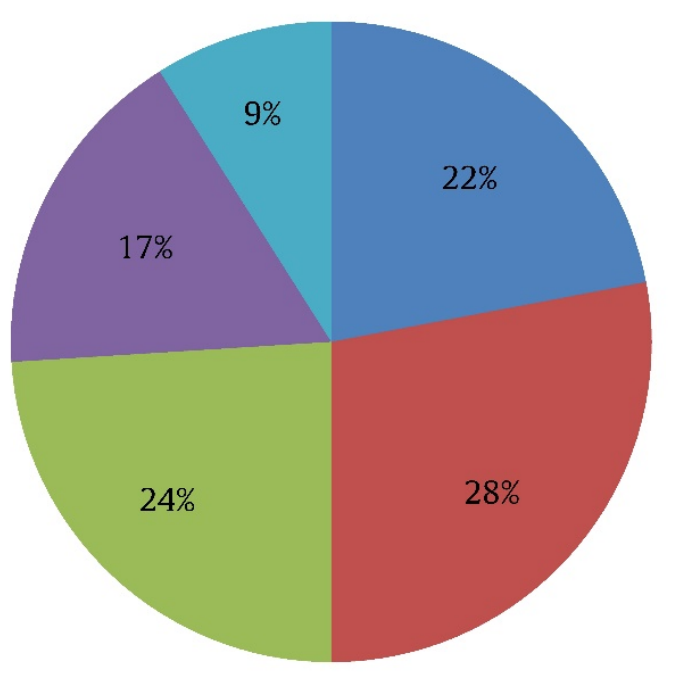

strongly disagree

disagree

neutral

agree

strongly agree

Figure 5. IT Governance Mechanisms

"It is wrong to suppose that if you can't measure it, you can't manage it - a costly myth." (Deming et al. 1982, p. 35). Deming clearly stressed the importance of data as a basis to make decisions. The meaning of Deming's statement is more that you must be able to manage even if there is no data available. Since Deming's statement, the world became digital, and almost any circumstance can be made available in digital form. Monitoring and evaluation is a central element of the ISO/IEC 38500 (2015) model and methods of measurement a mandatory factor of management. The quote in the digital era must be "if you manage it, measure it."

Figure 6 shows the results of methods of measurement in the context of monitoring IT. The results show that only $41 \%$ of asked Swiss companies do monitor their IT environment. However, 28\% agree that they measure and evaluate their IT environment on a regular basis. The result is also a statement of the maturity of IT management in Switzerland. 


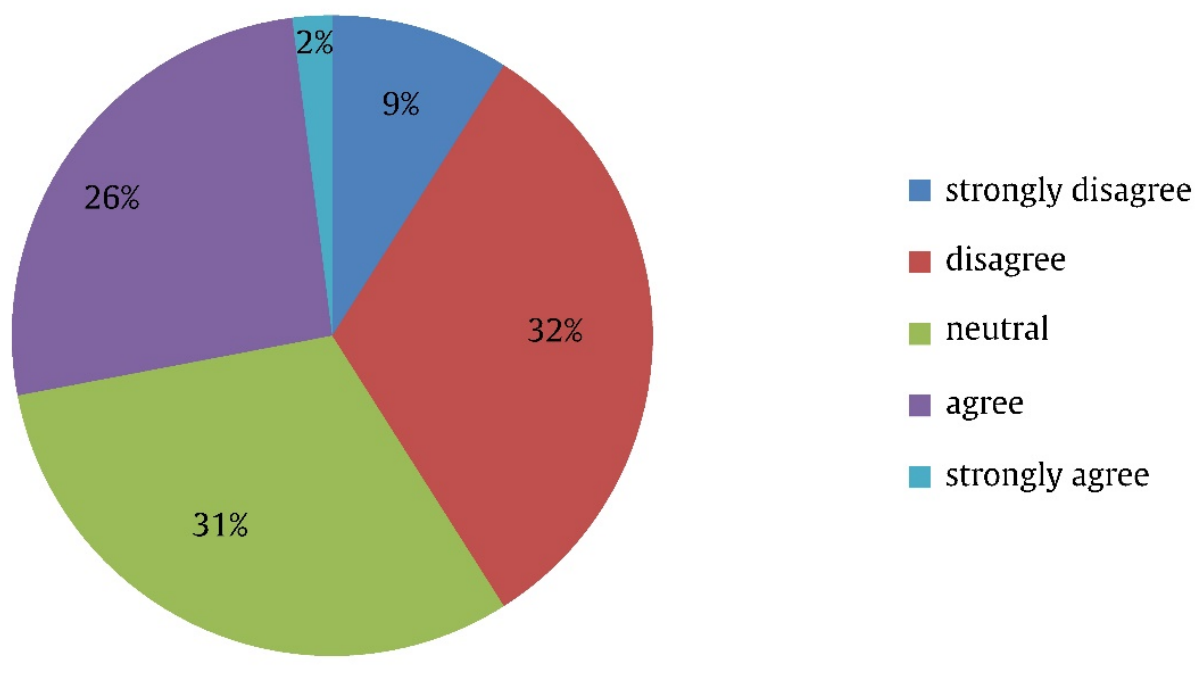

Figure 6. Methods of Measurement - Monitoring

Figure 7 shows the results of methods of measurement in the context of enrichment. The enrichment section reflects the existence of modern data enrichment and management methodologies. Comparing the results of monitoring and enrichment shows that there is a misunderstanding of monitoring of IT. Where $2 \%$ strongly disagree to monitoring of IT, 7\% claim to have data enrichment in place of it. But both results are very similar and underline the nonexistence of clear IT Governance structures.

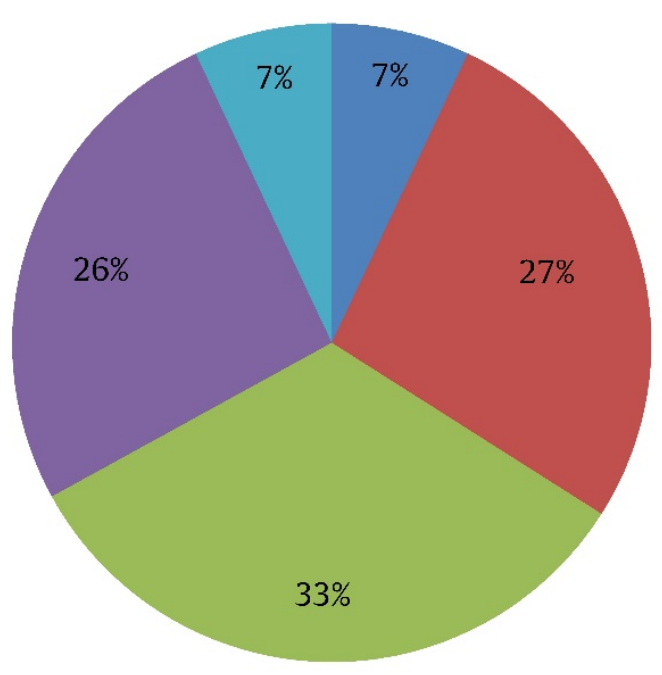

strongly disagree

disagree

neutral

agree

strongly agree

Figure 7. Methods of Measurement and Enrichment

All results concerning IT Governance show that only about $30 \%$ of the asked companies have a definition of IT Governance. The comparison with the Swiss study of Ruoss (2015), the conclusions of $\mathrm{Wu}$, et al. (2015) and Eom, et al. (2015) shows similarities and one 
can conclude that $56 \%$ of Swiss companies call their IT dinosaurs not due to a missing IT Governance but due to missing structures of modern strategic management and change management within the IT domain of knowledge. This could be solved ideally with IT Governance structures.

In the digital maturity section of the survey $50 \%$ of the Swiss companies that claimed not having a defined IT Governance claimed to have strong digital capabilities shown in Figure 8. This present state of digital capabilities was surprising and is controversial compared to the statements in the first section. This can be explained by the perceived image the middle management has of themselves.

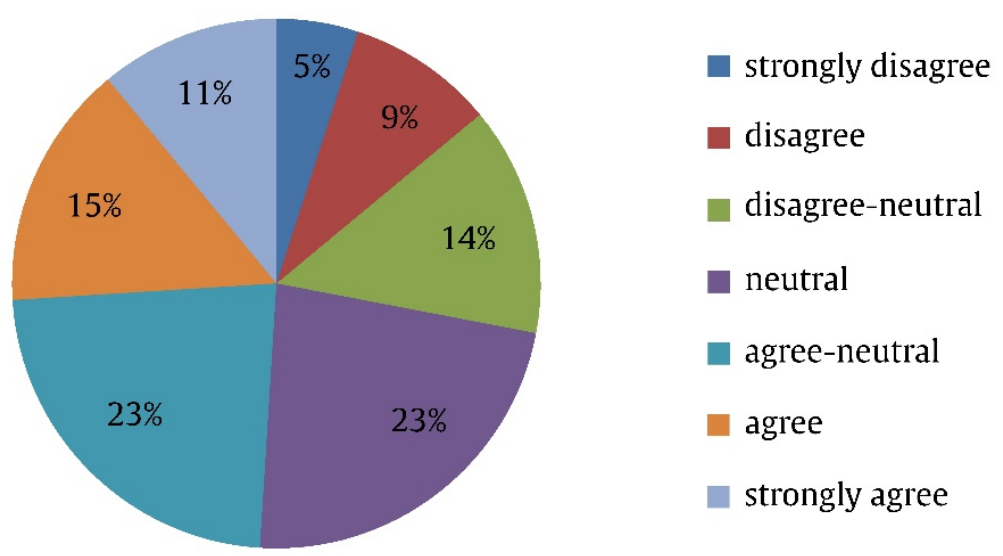

Figure 8. Digital Maturity - Present State (Digital Capability)

Figure 9 shows that a majority of middle managers, $51 \%$, see a perceived image of leadership capabilities in digital matters. Remembering that only $26 \%$ claim that the company has IT Governance mechanisms, also here there seems to be a misunderstanding of strategic management in the present state.

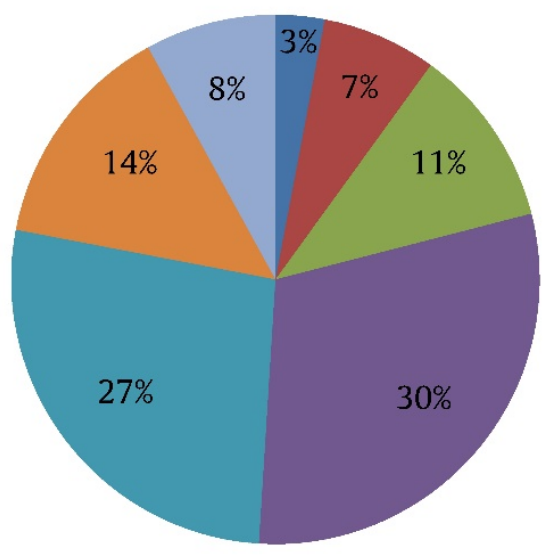

strongly disagree

disagree

disagree-neutral

neutral

agree-neutral

agree

strongly agree

Figure 9. Digital Maturity - Present State (Leadership Capability)

Finally, in Figures 10 and 11, the future state of digital capabilities and leadership capabilities in terms of digital transformation shows an even stronger perceived image of the middle 
management. The conclusion of the second section of the survey shows a mismatch with the results in IT Governance. IT Governance and its methods of monitoring is an organisational pre-requirement to manage digital initiatives. Many recent studies show that organisational performance is clearly linked to governance mechanisms.

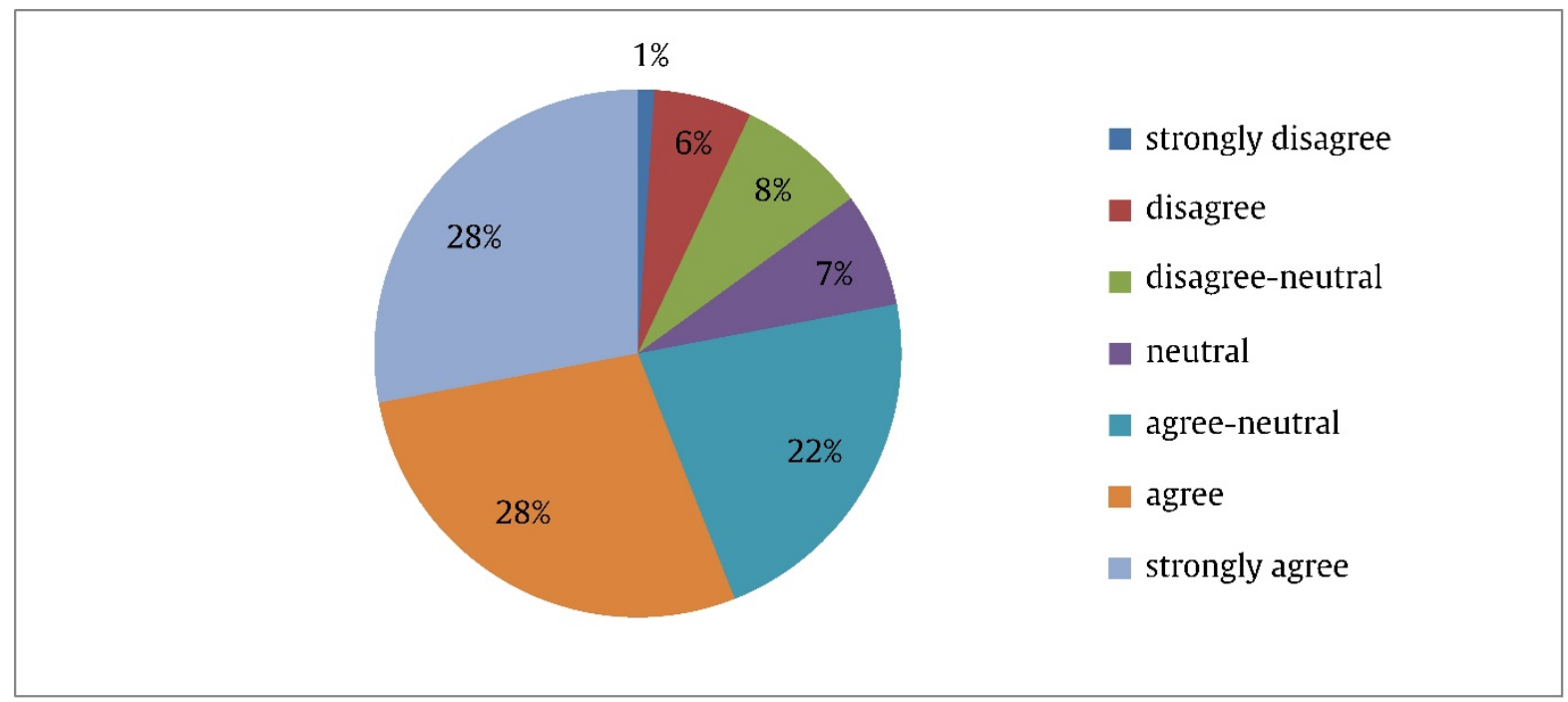

Figure 10. Digital Maturity - Future State (Digital Capability)

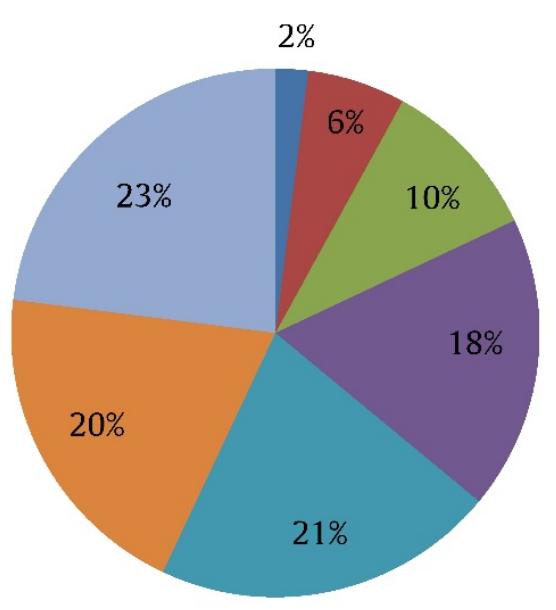

strongly disagree

disagree

disagree-neutral

neutral

agree-neutral

agree

strongly agree

Figure 11. Digital Maturity - Future State (Leadership Capability)

Figure 12 shows the Structural Equation Model (SEM) which is very similar to the equation model in $\mathrm{Wu}$, et al. (2015) study. The study of the digital readiness study comes to the same result. IT Governance Mechanisms describes IS Strategic Alignment by $28.6 \%$, and an even stronger relationship is between $I S$ Strategic Alignment and Organizational Performance by $53.4 \%$. However, the items in the constructs are quite different. The important effect of communication structures and decision-making structures are very week, where formal processes are seen as the strongest item towards IT Governance Mechanisms. This finding again reflects an understanding of IT in Swiss companies. Management, leadership, and communication seem to be delegated to formal processes. Surprisingly the same Swiss companies claim to have a perceived strong leadership capability, present and even stronger in the future. The comparison of the two sections of the study answer RQ3. There is obviously a misunderstanding of digital leadership, strategic 
IT management, IT Governance and transformational structures for change management. Questions in the IT Governance section of the survey verify the results of Ruoss (2015). Questions in the digital readiness section have shown the perceived image of the middle management of the asked Swiss companies.

The RQ3 can be answered with yes. It can be said that approximately a third of the asked
Swiss companies have well defined strategic IT management structures. This is more than the authors have expected. However, more than one-third of companies claim that they have strong digital leadership capabilities. One must distinguish between as is structures and the perceived image of the management. It is reasonable that the middle management answers differently, when asked about their capabilities than others.

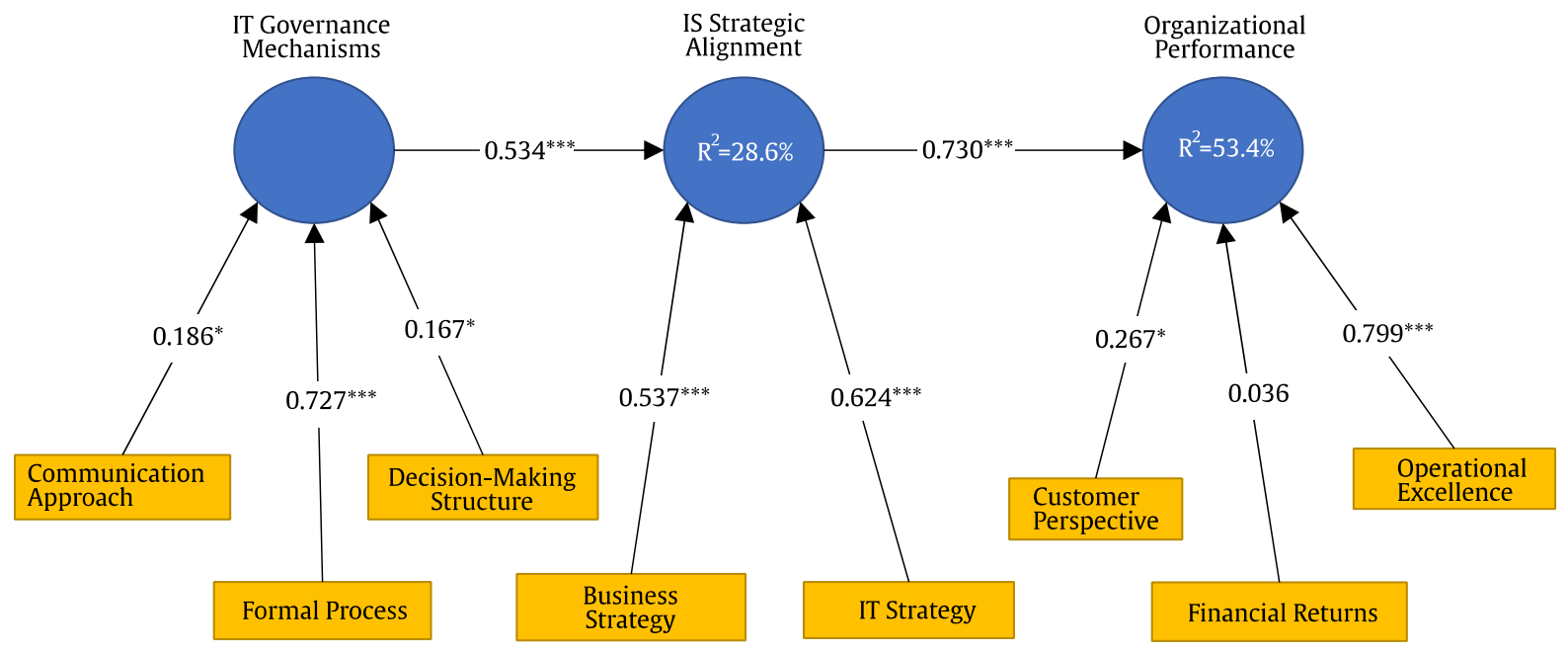

P-values: ${ }^{* * *} \mathrm{p}<0.001 ;{ }^{* *} \mathrm{p}<0.01 ; \mathrm{p}^{*}<0.05$

Figure 12. Structural Equation Model

\section{FUTURE RESEARCH}

In the first outcome of this paper, the nature of digital business models and the required operating model have been discussed. The method of measurement for monitoring such an operating model is a key element of modern IT government mechanisms. In the second outcome the discussion of various studies, including a replicated study done in spring 2017 in Switzerland, showed that even in traditional operating models, the majority have neither IT Governance mechanisms nor methods of measurement of IT. Future research should, therefore, concentrate on methods of measurement in the context of digital business models.

\section{REFERENCES}

Ali, S. and Green, P. (2012). Effective information technology (IT) governance mechanisms: An IT outsourcing perspective. Information Systems Frontiers. 14 (2), pp. 179-193.
Baets, W. (1992). Aligning information systems with business strategy. The Journal of Strategic Information Systems 1 (4), pp. 205-213.

Bashir, M. and Yousaf, A. and Verma, R. (2016). Disruptive Business Model Innovation: How a Tech Firm is Changing the Traditional Taxi Service Industry. In Indian Journal of Marketing 46 (4), pp. 49-59.

Bracken, J. (2014). The Important Difference between Change and Transition. Retrieved July 04, 2016 from http://qualitytexas.org/wp-content/uploads/2014/11/TheImportant-Difference-between-Changeand-Transition.pdf

Bridges, W. (1991). Managing transitions: Making the most of change: Perseus Books.

Brown, A. E., and Grant, G. G. (2005). Framing the frameworks. A review of IT governance research. In Communications of the Association for Information Systems 15 (1), p. 38. 
Brühn, T and Götz, G. and Peitz, M. and Rebler, A. and Schwalbe, U. and Heinrichs, H. et al. (2014). Die Modelle Uber und Airbnb: Unlauterer Wettbewerb oder eine neue Form der Sharing Economy? In Ifo Schnelldienst 67 (21), pp. 3-27. DOI: 10.3726/978-3-653-03858-3.

Ceruzzi, P. E. (2003). A history of modern computing: MIT press.

Chan, Y. E. and Reich, B. H. (2007). IT alignment. What have we learned? In J Inf Technol 22 (4), pp. 297-315. DOI: 10.1057/palgrave.jit.2000109.

Cooper, H. M. (1988). Organizing knowledge syntheses. A taxonomy of literature reviews. In Knowledge in Society 1 (1), pp. 104-126. DOI: $10.1007 / B F 03177550$.

Deming, W. E. (1982). Quality, productivity, and competitive position: Cambridge, Mass. : Massachusetts Institute of Technology, Center for Advanced Engineering Study.

Detsky, A. S. and Garber, A. M. (2016). Uber's Message for Health Care. In NEngl J Med 374, pp. 806-809. Retrieved July 04, 2016 from https://pdfs.semanticscholar.org/57ce/ef015 e3d98c243c369075effffb2681ddaa6.pdf

Eom, M. and Kahai, S. and Yayla, A. (2015). Investigation of How IT Leadership Impacts IT-Business Alignment through Shared Domain Knowledge and Knowledge Integration. Retrieved October 05, 2016 from http://pilotscholars.up.edu/bus_facpubs/21/

Fink, K. and Ploder, K. (2008). Decision support framework for the implementation of ITgovernance. In: Hawaii International Conference on System Sciences, Proceedings of the 41st Annual. IEEE, p. 432.

Gartner Group (Ed.) (2014). Gartner Says Digital Business Economy is Resulting in Every Business Unit Becoming a Technology Startup. Retrieved July 05, 2015 from http://www.gartner.com/newsroom/id/286 5519

Goltsche, W. (2007). COBIT kompakt und verständlich: Der Standard zur IT Governance - So gewinnen Sie Kontrolle über Ihre IT - So steuern Sie Ihre IT und erreichen Ihre Ziele: Vieweg+Teubner Verlag.

de Haes, S. and van Grembergen, W. (2015). Enterprise governance of information technology. Achieving alignment and value, featuring COBIT 5. 2. ed. Cham: Springer (Management for professionals).

Hanschke, I. (2010). Strategic IT management. A toolkit for enterprise architecture management. Berlin: Springer.

Hernaus, T. (2008). Generic process transformation model: transition to process-based organization. In $E F Z G$ Working Paper Series/EFZG Serija članaka u nastajanju 08 (07), pp. 1-16.

Hevner, A. R., and March, S. T. and Park, J. and Ram, S. (2004). Design Science in Information Systems Research. In Mis Quarterly 28 (1), pp. 75-105.

Hevner, A. R. (2007). A three cycle view of design science research. In Scandinavian journal of information systems 19 (2), p. 4.

ISO/IEC (2015). ISO/IEC 38500:2015 Information technology - Governance of IT for the organization, 2nd Ed. 1st Version. Retrieved July 04, 2016 from https://www.iso.org/obp/ui/\#iso:std:isoiec:38500:ed-2:v1:en

ISO/IEC (2014). ISO/IEC TR 38502:2014, Information technology - Governance of IT Framework and model, 1st Ed. 1st Version. Retrieved July 04, 2016 from https://www.iso.org/obp/ui/\#iso:std:isoiec:tr:38502:ed-1:v1:en

Johanning, V. (2014). IT-Strategie: Optimale Ausrichtung der IT an das Business in 7 Schritten. $1^{\text {st }}$ ed. Wiesbaden: Springer Science and Business Media.

Kagermann, H. (2011). IT-driven business models. Global case studies in transformation. Hoboken, N.J: John Wiley \& Sons.

Kagermeier, A. and Köller, J. and Stors, N. (2015). Airbnb als Share Economy Herausforderung für Berlin und die Reaktionen der Hotelbranche. In Mit Auto, Brille, Fon und Drohne. Neues Reisen im 21. DOI: 10.1515/tw-2015-0203.

Kim, W. Chan; Mauborgne, Renée (2004). Blue ocean strategy. In Harvard Business Review's Must-Reads on Strategy, p. 71.

Kling, R. (1996). Computerization and controversy: value conflicts and social choices: Morgan Kaufmann.

Lauer, T. (2014). Change Management Grundlagen und Erfolgsfaktoren. $2^{\text {nd }}$ ed. 
Berlin, Heidelberg: Springer.

Likert, R. (1932). A technique for the measurement of attitudes. In Archives of psychology.

Lubke, G. H. and Muthén, B. O. (2004). Applying multigroup confirmatory factor models for continuous outcomes to Likert scale data complicates meaningful group comparisons. In Structural Equation Modeling 11 (4), pp. 514-534.

Maryska, M. and Doucek, P. and Nedomova, L. (2015). Corporate Informatics and Strategic Management. In Procedia Economics and Finance 26, pp. 651-656. DOI: 10.1016/S2212-5671(15)00806-0.

OECD Council (2005). Growth in Services. Retrieved July 04, 2016 from http://www.oecd.org/general/34749412.pdf

Österle, H. and Otto, B. (2010). Konsortialforschung. Eine Methode für die Zusammenarbeit von Forschung und Praxis in der gestaltungsorientierten Wirtschaftsinformatikforschung. In Wirtschaftsinformatik: WI52 (5), pp. 273285.

Otremba, S. (2016). GRC-Management als interdisziplinäre Corporate Governance : Die Integration von Revision, Risiko- und Compliance-Management in Unternehmen. Wiesbaden: Springer Gabler.

Peffers, K. and Tuunanen, T. and Rothenberger, M. A. and Chatterjee, S. (2007). A design science research methodology for information systems research. In Journal of management information systems 24 (3), pp. 45-77.

Perroud, T. and Inversini, R. (2013). Enterprise Architecture Patterns. Practical Solutions for Recurring IT-Architecture Problems. Berlin, Heidelberg, s.l.: Springer Berlin Heidelberg.

Pescher, J. (2010). Change Management: Taxonomie und Erfolgsauswirkungen: Springer.

Potůček M. and Veselý, A. and Nekola, M. (2004). Understanding Governance: Theory, Measurement and Practice. Measurement of Governance. In CESES Papers (1). Retrieved July 04, 2016 from http://www.ceses.cuni.cz/CESES-20version1-sesit04_05_potucek.pdf

Snyder, M. (2014). Achieving successful IT transformation: 11 lessons from the field.
Retrieved October 05, 2016 from https://home.kpmg.com/content/dam/kpmg /ke/pdf/markets/insurance/11-lessons-forit-transformation-success.pdf

Sonnenberg, C. and Vom Brocke, J. (2012). Evaluations in the Science of the Artificial Reconsidering the Build-Evaluate Pattern in Design Science Research. In David Hutchison, Takeo Kanade, Josef Kittler, Jon M. Kleinberg, Friedemann Mattern, John C. Mitchell et al. (Eds.): Design Science Research in Information Systems. Advances in Theory and Practice, vol. 7286. Berlin, Heidelberg: Springer Berlin Heidelberg (Lecture Notes in Computer Science), pp. 381-397.

Robbins, S. P. and Coulter, M. (2010). Management. 11. ed., global ed. Boston: Pearson.

Ruoss, S. (2015). Digital Switzerland 2015 (abstract). Hochschule für Wirtschaft Zürich HWZ.

Venkatraman, N. and Henderson, J.C. and Oldach, Scott (1993). Continuous strategic alignment: Exploiting information technology capabilities for competitive success. In European Management Journal 11 (2), pp. 139-149.

Webb, P. and Pollard, C. and Ridley, G. (2006). Attempting to define IT governance. Wisdom or folly? In : System Sciences, 2006. HICSS'06. Proceedings of the 39th Annual Hawaii International Conference on, vol. 8. IEEE, 194a-194a.

Weill, P. and Ross, J. W. (2004). IT governance. How top performers manage IT decision rights for superior results. Boston: Harvard Business School Press.

Westerman, G. and Bonnet, D. and McAfee, A. (2014). Leading digital. Turning technology into business transformation. Boston, Mass.: Harvard Business Review Press.

Westerman, G. and Calméjane, C. and Bonnet, D. and Ferraris, P. and McAfee, A. (2011). Digital Transformation. A roadmap for billion-dollar organizations. In MIT Center for Digital Business and Capgemini Consulting, pp. 1-68.

Wu, S. P., and Straub, D. W. and Liang, T. (2015). How information technology governance mechanisms and strategic alignment influence organizational performance: Insights from a matched survey of business 
and IT managers. In Mis Quarterly 39 (2), pp. 497-518.

www.inside-it.ch (2015). Wie steht es um die digital Fitness Schweizer Unternehmen? Retrieved July 02, 2016 from http://www.inside-it.ch/articles/40679

Zachman, J. A. (1987). A framework for information systems architecture. In IBM systems journal26 (3), pp. 276-292.

\section{ABOUT THE AUTHORS}

Karlheinz Schwer, schk08@vse.cz

Mr. Karlheinz Schwer is a Ph.D. student at the University of Economics in Prague. He works as a lecturer and management consultant at the Zurich University of Applied Sciences in Switzerland. Before that, he worked as a management consultant on projects in various industries.

Mr. Christian Hitz is a Ph.D. student at the University of Economics in Prague. He works as a lecturer and management consultant at the Zurich University of Applied Sciences (ZHAW) in Switzerland. He is also head of the IT Strategy \& Management department at the ZHAW School of Management and Law. Before that, he worked as a management consultant on projects in various industries. 
Appendix 1: Sample questionnaire block

"Methods of Measurement" with Likert scale

I目 Methods of Measurement

For each of the following statements, please choose the the methods of measurement of your company.

Scale:

SD (Strongly Disagree)

$\mathrm{D}$ (Disagree)

$\mathrm{N}$ (Neutral)

A (Agree)

SA (Strongly Agree)

a) Managerial Behavior

MM1 Our company's management has a top down c cision making.

MM2 Our company's management has a consultati involving all levels of management in decision

MM3 Our company's management culture is knowr compared to other companies in the same ind 